\title{
Analisis dan Kontrol Optimal pada Model Penyebaran Virus HIV dengan Peran Respon Imun dan Terapi Antiretroviral
}

\author{
Sinta Armadi Putri, Hariyanto, dan Nur Asiyah \\ Depatemen Matematika, Fakultas Matematika, Komputasi, dan Sains Data, Institut Teknologi Sepuluh \\ Nopember \\ e-mail: sintarmadiputri@yahoo.com
}

\begin{abstract}
Abstrak-Human Immunodeficiency Virus (HIV) merupakan salah satu virus yang menyebabkan penyakit AIDS, suatu kondisi pada manusia dimana sistem kekebalan tubuh mulai menurun dan menyebabkan infeksi oportunistik. Virus ini menyerang sel $C D 4^{+} T$ dalam tubuh, semakin berkurangnya jumlah sel $C D 4^{+} T$ dalam tubuh maka akan semakin cepat virus ini berkembang menjadi penyakit AIDS. Tidak ada obat yang benar-benar menyembuhkan, yang dapat dilakukan hanyalah menghambat penyebaran virus sehingga dapat meningkatkan masa hidup orang yang terinfeksi. Dan untuk mengatasi permasalahan tersebut, pada penelitian ini akan dilakukan pemberian kendali optimal berupa terapi antiretroviral yaitu Reverse transcriptase inhibitor $\left(\eta_{r}\right)$ dan protease inhibitor $\left(\eta_{p}\right)$ pada model penyebaran virus HIV. Dengan menerapkan prinsip maksimum pontryagin, hasil simulasi menunjukkan bahwa jumlah sel $C D 4^{+} T$ meningkat hingga $20 \%$ dimana efisiensi sebuah pengontrol berupa terapi antiretoviral $\left(\eta_{r}\right)$ adalah 99\% dalam memblokir infeksi baru dan $\left(\boldsymbol{\eta}_{p}\right)$ adalah $100 \%$ dalam menghambat produksi virus baru.
\end{abstract}

Kata Kunci-HIV, sel $\mathrm{CD}^{+} \mathrm{T}$, Reverse transcriptase inhibitor, protease inhibitor.

\section{PENDAHULUAN}

B AKTERI patogen adalah organisme atau mikroorganisme yang menyebabkan penyakit pada organisme lain. Bakteri patogen ini bekerja dengan cara menginfeksi organisme dan akibatnya, muncul gejala-gejala abnormal yang biasa disebut dengan tanda-tanda penyakit. Sebagian dari bakteri patogen ini tidak terasa di tubuh, namun tidak jarang pula yang menyebabkan penyakit serius semacam HIV. HIV merupakan retrovirus yang menginfeksi sel-sel $C D 4^{+} T$ dan makrofag dari sistem kekebalan tubuh. Virus HIV akan memperburuk sistem kekebalan tubuh seseorang saat infeksi berkembang. Tahap utama infeksi memakan waktu sekitar 10-15 tahun untuk berkembang menjadi penyakit AIDS [1].

Dari data GHO pada tahun 2014 yang paling baru tentang HIV/AIDS yang diterbitkan oleh WHO menyatakan bahwa sekitar 78 juta orang telah terinfeksi virus HIV dan sekitar 39 juta orang telah meninggal karena virus HIV. Dalam kasus ini sekitar 35,0 juta orang hidup dengan HIV secara global. Namun demikian, beban HIV dapat bervariasi tergantung pada wilayah geografis, misalnya seperti Sub-Sahara Afrika adalah wilayah yang paling terkena dampak yang memberikan kontribusi hampir $70 \%$ dari beban global HIV [2].

Sampai saat ini, belum ada pengobatan yang benar-benar dapat menyembuhkan atau menghilangkan virus HIV, namun ada langkah-langkah preventif yang dapat membantu dalam mengendalikan infeksi dan meningkatkan masa hidup orang yang terinfeksi yaitu dengan memanfaatkan peran respon imun dan melakukan terapi antiretroviral. Terapi ini berupa pemberian obat antiretroviral yang dapat mengendalikan infeksi dan bekerja berdasarkan tahapan siklus hidup virus dengan cara yang berbeda [3].

Banyak peneliti yang mengembangkan model dinamika infeksi virus HIV dengan segala permasalahannya, salah satunya adalah Wang dkk [4] yang mengkonstruksi model dinamika infeksi virus HIV dengan menggabungkan respon imun dan kombinasi terapi, kemudian dikembangkan kembali oleh Preety Dubey dkk [1] dengan mengkonstruksi model dinamika infeksi virus HIV yang melibatkan peran antibodi dalam mengendalikan virus. Serta penelitian yang dikembangkan oleh Nastitie [5] berupa pemberian kendali optimal untuk pengobatan kanker dengan menggabungkan kombinasi terapi dalam meminimalkan ukuran kanker, yang dapat diterapkan untuk penelitian yang akan dilakukan pada makalah ini yaitu analisis perilaku sistem dan memperoleh kontrol optimal dengan menggunakan Prinsip Maksimum Pontryagin (PMP) dari model penyebaran virus HIV. Penelitian ini bertujuan untuk meningkatkan jumlah sel $C D 4^{+} T$ dengan biaya pemberian obat terapi antiretroviral yang minimum sehingga dapat menekan penyebaran virus HIV dan mengurangi jumlah sel $C D 4^{+} T$ yang terinfeksi, cara ini dilakukan agar dapat meningkatkan masa hidup orang yang terjangkit virus HIV tiap tahunnya. Model Preeti Dubey dkk [1] yang digunakan pada penelitian ini melibatkan sel $C D 4^{+} T$ yang tidak terinfeksi, sel yang terinfeksi, virus HIV, respon imun yang didapat yaitu cytotoxic $T$ lymphocyte (CTL) dan respon kekebalan tubuh (antibodi). Dengan asumsi bahwa stimulasi diri dari CTL terjadi karena adanya sel yang terinfeksi virus serta respon dalam menghadapi sel terinfeksi dan stimulasi diri dari antibodi terjadi karena adanya virus bebas. Selanjutnya, perilaku sistem akan direpresentasikan dalam bentuk simulasi menggunakan software MATLAB R2013a.

\section{II.DASAR TEORI}

\section{A.Human Immunodeficiency Virus (HIV)}

Human Immunodeficiency Virus (HIV) adalah retrovirus yang menginfeksi sel-sel $C D 4^{+} T$ yang normalnya digunakan untuk pengenalan antigen tetapi digunakan untuk pengikatan dan menyerang sistem kekebalan tubuh dengan menghancurkan atau mengganggu fungsinya. HIV 
merupakan agen penyebab AIDS, menyerang salah satu jenis dari sel-sel darah putih yang bertugas menangkal infeksi. HIV merupakan suatu virus yang didalamnya terdapat protein inti yang dikelilingi 2 molekul RNA rantai tunggal, dan melakukan replikasi menggunakan sel $C D 4^{+} T$ sebagai alat untuk memperbanyak diri dan menyebar ke seluruh tubuh dengan mengandalkan enzim reverse transcriptase [6].

Sel $C D 4^{+} T$ mempercepat produksi antibodi oleh sel B, serta dapat menghasilkan zat-zat yang mengaktifkan sel $\mathrm{T}$ sitotoksik dan sel-sel darah putih yang dikenal sebagai makrofag. Sel-sel $C D 4^{+} T$ ditargetkan oleh HIV sebagai inang dan menghancurkannya dengan memicu sinyal yang mengakibatkan kematian sel. Sel T sitotoksik terlibat dalam penghancuran langsung sel-sel yang telah menjadi kanker atau terinfeksi virus. Sel T sitotoksik mengandung butiran (kantung yang berisi enzim pencernaan atau zat kimia lainnya) sehingga mereka memanfaatkannya untuk menyebabkan sel target pecah dalam proses yang disebut apoptosis. Sel T menyerang jaringan organ asing saat organ transplantasi diidentifikasi sebagai jaringan yang terinfeksi. Respon sel sitotoksik menghambat replikasi virus dan berperan penting dalam kontrol awal infeksi HIV dan mengendalikan setpoint virus [7].

Antibodi adalah suatu glikoprotein yang dihasilkan oleh sel B limfosit dan merupakan sistem pertahanan tubuh melalui sistem kekebalan tubuh (imunitas) untuk membunuh dan menetralisir zat-zat asing yang masuk ke dalam tubuh yang dapat membahayakan tubuh, seperti bakteri, virus atau zat kimia lainnya. Antibodi dapat menghentikan aktivitas antigen yang merusak dengan cara mengikatkan antibodi pada antigen sehingga permukaannya menjadi lebih mudah menempel pada makrofag dan menjauhkan antigen tersebut dari sel yang ingin dirusak. Antibodi juga mempersiapkan antigen untuk dimakan oleh makrofag [8].

Pengobatan yang dapat dilakukan untuk penderita HIV saat ini adalah menggunakan Terapi Antiretroviral (ART). Terapi ini berupa obat HIV yang digunakan untuk mengatasi infeksi HIV dengan cara menghambat HIV pada tahap siklus hidupnya. Ada berbagai kelas obat HIV, setiap kelas mempunyai cara yang berbeda untuk melawan HIV. Setiap harinya, pasien HIV menggunakan kombinasi obat HIV setidaknya 2 kelas obat HIV yang berbeda. Konsumsi rutin dari obat-obatan HIV dapat membantu penderita HIV hidup lebih lama dan lebih sehat [3].

\section{B.Model Matematika}

Model matematika dikonstruksi berdasarkan pada interaksi antara sel $C D 4^{+} T$ yang tidak terinfeksi $x(t)$, sel $C D 4^{+} T$ yang terinfeksi $y(t)$, virus $v(t)$ dan kedua komponen dari respon imun yang diperoleh yaitu sel sitotoksik (CTL) $C(t)$ dan antibodi $A(t)$. Model persamaan differensial biasa lima dimensi diberikan sebagai [1] :

$\dot{x}=\omega+r x\left(1-\frac{x}{x_{m}}\right)-\omega_{0} x-\beta\left(1-\eta_{r}\right) x v$

$\dot{y}=\beta\left(1-\eta_{r}\right) x v-\delta_{0} y-k_{1} C y$

$\dot{v}=N \delta_{0}\left(1-\eta_{P}\right) y-\delta_{1} v-k_{2} A v$

$\dot{C}=\alpha_{1} y+\mu_{1} C y-\mu_{10} C$

$\dot{A}=\mu_{2} v A-\mu_{20} A$

$x(0)>0, \quad y(0) \geq 0, \quad v(0) \geq 0, \quad C(0) \geq 0, \quad A(0) \geq 0$. dengan nilai parameter sebagai berikut [1]:
Tabel 1

Variabel Keadaan dan Nilai Parameter Model Penyebaran Virus HIV

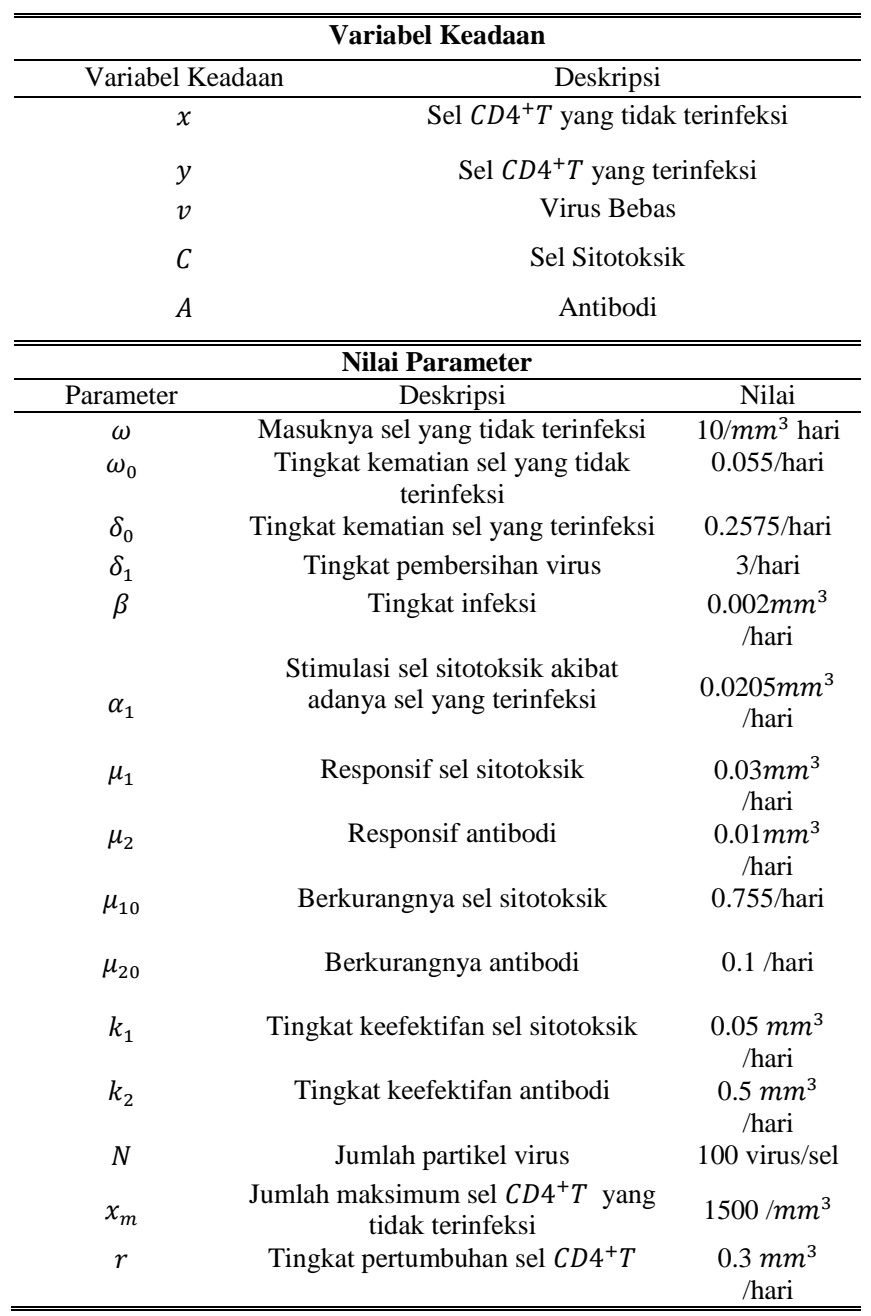

\section{Analisis Dinamika Penyebaran Virus HIV}

Analisis dinamika model dilakukan untuk mengetahui perilaku sistem pada model dinamik penyebaran virus HIV. Pada penelitian ini akan dianalisis mengenai kestabilan di sekitar titik kesetimbangan dan keterkontrolan sistem.

\section{1) Titik Kestimbangan}

Diberikan suatu persamaan differensial:

$$
\dot{x}(t)=f(x(t)), \quad x\left(t_{o}\right)=x_{0}
$$

dengan $x(t) \in R^{n}$, vektor $\bar{x}$ yang memenuhi $f(\bar{x})=0$.

Definisi 1 [9]

Titik $\bar{x} \in \mathbb{R}^{n}$ disebut titik kesetimbang dari suatu sistem jika $f(\bar{x})=0$.

\section{2) Kestabilan Sistem}

Matriks Jacobian $J(f(\bar{x}))$ dapat digunakan untuk mengidentifikasi sifat kestabilan sistem nonlinier disekitar titik ekuilibrium $\bar{x}$ asalkan titik kesetimbangan tersebut hiperbolik. Berikut diberikan definisi tentang matriks jacobian dan titik kesetimbangan hiperbolik.

Definisi 2 [9]

Diberikan fungsi $f=\left(f_{1}, f_{2}, \ldots, f_{n}\right)$ dengan $f_{i} \in$ $C^{1}(E), I=1,2,3, \ldots, n, E \subseteq \mathbb{R}^{n}$ dan $E$ himpunan terbuka. Matriks dinamakan matriks Jacobian dari f pada titik $\bar{x}$ 


$$
J(f(\bar{x}))=\left(\begin{array}{ccc}
\frac{\partial f_{1}(\bar{x})}{\partial x_{1}} & \frac{\partial f_{1}(\bar{x})}{\partial x_{2}} & \cdots \frac{\partial f_{1}(\bar{x})}{\partial x_{n}} \\
\frac{\partial f_{2}(\bar{x})}{\partial x_{1}} & \frac{\partial f_{2}(\bar{x})}{\partial x_{2}} & \cdots \frac{\partial f_{2}(\bar{x})}{\partial x_{n}} \\
\vdots & \vdots & \ddots \vdots \\
\frac{\partial f_{n}(\bar{x})}{\partial x_{1}} & \frac{\partial f_{n}(\bar{x})}{\partial x_{2}} & \cdots \frac{\partial f_{n}(\bar{x})}{\partial x_{n}}
\end{array}\right)
$$

Definisi 3 [9]

Titik kesetimbangan $\bar{x}$ dikatakan hiperbolik jika semua nilai eigen matriks Jacobian $J(f(\bar{x}))$ mempunyai bagian real tak nol.

Berikut diberikan definisi mengenai sifat kestabilan suatu sistem nonlinier yang ditinjau dari nilai eigen matriks Jacobian.

\section{Definisi 4 [9]}

Suatu titik kesetimbangan $\bar{x}$ pada sistem persamaan diferensial $\dot{x}=f(x)$ dikatakan

1. Stabil, jika sетиa nilai eigen matriks Jacobian $J(f(\bar{x}))$ mempunyai bagian real negatif,

2. Tidak stabil, jika ada nilai eigen matriks Jacobian $J(f(\bar{x}))$ mempunyai bagian real positif.

Dalam beberapa permasalahan tertentu kestabilan dari titik setimbang tidak dapat diamati karena tanda bagian real dari nilai eigen tidak mudah ditentukan. Oleh karena itu dibutuhkan metode yang dapat digunakan untuk menentukan tanda bagian real dari akar-akar persamaan karakteristik tanpa mencari akar-akar persamaan karakteristik terlebih dahulu. Salah satu metode yang dapat digunakan adalah kriteria Routh-Hurwitz.

Teorema 5 [10] :

Diberikan persamaan karakteristik

$q(s)=a_{n} s^{n}+a_{n-1} s^{n-1}+\cdots+a_{1} s+a_{0} \quad a_{n} \neq 0$

Kemudian disusun tabel sebagai berikut:

$$
\begin{array}{c|cccc}
s^{n} & a_{n} & a_{n-2} & a_{n-4} & \ldots \\
s^{n-1} & a_{n-1} & a_{n-3} & a_{n-5} & \ldots \\
s^{n-2} & b_{1} & b_{2} & b_{3} & \\
s^{n-3} & c_{1} & c_{2} & c_{3} & \\
\vdots & \vdots & & & \\
s^{0} & q & &
\end{array}
$$

dimana $b_{1}, b_{2}, \ldots, c_{1}, c_{2}, \ldots$ dan $q$ secara rekursif didapat dari:

$b_{1}=\frac{a_{n-1} a_{n-2}-a_{n} a_{n-3}}{a_{n-1}} \quad, b_{2}=\frac{a_{n-1} a_{n-4}-a_{n} a_{n-5}}{a_{n-1}} \quad, \ldots$

$c_{1}=\frac{b_{1} a_{n-3}-b_{2} a_{n-1}}{b_{1}}, c_{2}=\frac{b_{1} a_{n-5}-b_{3} a_{n-1}}{b_{1}}, \ldots$

1. Jika banyaknya perubahan tanda dalam kolom pertama pada tabel diatas maka sistem tidak stabil.

2. Jika pada kolom pertama dalam tabel tidak ada perubahan tanda (semuanya bertanda positif atau semuanya bertanda negatif), maka semua akar polinomial $q(s)$ bagian realnya adalah tak positif dan sistem bersifat stabil.

\section{3) Keterkontrolan Sistem}

Analisis Keterkontrolan sistem sangat perlu dilakukan karena pada dasarnya untuk memperoleh solusi dari suatu permasalahan kontrol optimal haruslah sistem tersebut dapat dikontrol jika tidak maka kontrol optimal tidak akan didapatkan.

Teorema 6 [10] :

Jika terdapat persamaan matriks state sebagai berikut:

$$
\dot{x}(t)=A x(t)+B u(t)
$$

$$
y(t)=C x(t)
$$

Maka syarat perlu dan cukup sistem terkontrol adalah:

$$
M_{c}=\left[B|A B| A^{2} B|\ldots| A^{n-1} B\right]
$$

Mempunyai rank sama dengan $n$.

\section{D.Kendali Optimal}

Pada umumnya masalah kontrol optimal bertujuan untuk mencari kontrol $u(t)$ yang akan diproses dalam sistem dinamik dan dapat mengoptimalkan indeks performansi [11]. Adapun masalah formulasi kendali optimal terdiri dari:

1. Mendeskripsikan secara matematis dari model (dalam bentuk variabel state).

2. Menentukan fungsi objektif (performance index).

3. Menentukan kendala dan kondisi batas yang harus di penuhi.

Fungsi objektif (performance index) dapat diformulasikan sebagai berikut :

$J=S\left(x\left(t_{f}\right), t_{f}\right)+\int_{t_{0}}^{t_{f}} V(x(t), u(t), t) d t$

dengan kendala:

$x(t)=f(x(t), u(t), t)$

dan kondisi batas $x\left(t_{0}\right)=x_{0}$ dan $x\left(t_{f}\right)=x_{f}, t_{0}$ dan $t_{f}$ masing-masing adalah waktu awal dan akhir. $S, V$, dan $f$ adalah fungsi skalar.

Serta kontrol $u^{*}(t)$ merupakan kontrol optimal, jika disubstitusikan ke dalam sistem (4) akan memperoleh keadaan yang optimal $x^{*}(t)$ dan pada saat yang sama juga dapat mengoptimalkan indeks performansi (3).

\section{E. Prinsip Maksimum Pontryagin}

Prinsip Maksimum Pontryagin adalah metode untuk memperoleh penyelesaian kendali optimal. Secara umum langkah-langkah penyelesaian kendali optimal dapat diuraikan sebagai berikut [11]:

1. Bentuk fungsi Pontryaginnya (Hamilton)

$$
\begin{aligned}
& H(x(t), u(t), g(t), t) \\
& =V(x(t), u(t), t)+g(t) f(x(t), u(t), t)
\end{aligned}
$$

2. Maksimumkan $H$ terhadap semua vektor kendali $u(t)$

$$
\begin{aligned}
& \frac{\partial H}{\partial u}=0 \\
& \text { dan diperoleh, } \\
& u *(t)=h\left(x^{*}(t), g^{*}(t), t\right)
\end{aligned}
$$

3. Gunakan hasil dari langkah 2 ke dalam langkah 1 dan tentukan $H^{*}$ yang optimal

$$
\begin{aligned}
H^{*}\left(x^{*}(t), h\left(x^{*}(t),\right.\right. & \left.\left.g^{*}(t), t\right), g(t), t\right) \\
= & h\left(x^{*}(t), g^{*}(t), t\right)
\end{aligned}
$$

4. Selesaikan persamaan state dan costate

$$
x^{*}(t)=+\frac{\partial H}{\partial \lambda} \quad \text { dan } \quad g^{*}(t)=+\frac{\partial H}{\partial x}
$$

dengan kondisi awal $x_{0}$ dan kondisi transversality. Kondisi batas transversality dibedakan menjadi lima tipe berdasarkan perbedaan antara $t_{f}$ dan state pada waktu dan akhir $x\left(t_{f}\right)$, antara lain:

- Waktu akhir dan state saat waktu akhir telah ditentukan atau diketahui

$$
x\left(t_{0}\right)=x_{0}, x\left(t_{f}\right)=x_{f}
$$

- Waktu akhir belum ditentukan atau tidak diketahui dan state saat waktu akhir telah ditentukan atau diketahui

$$
x\left(t_{0}\right)=x_{0}, x\left(t_{f}\right)=x_{f},\left(H^{*}+\frac{\partial s}{\partial t}\right)_{t_{f}}
$$


- Waktu akhir telah ditentukan atau diketahui sedangkan state saat waktu akhir belum diketahui atau ditentukan

$$
x\left(t_{0}\right)=x_{0}, g^{*}\left(t_{f}\right)=\left(\frac{\partial s}{\partial t}\right)_{* t_{f}}
$$

- Waktu akhir belum ditentukan dan state saat akhir belum ditentukan, serta nilainya bergantung pada sesuatu

$$
\begin{aligned}
& x\left(t_{0}\right)=x_{0}, x\left(t_{f}\right)=\varphi\left(t_{f}\right) \\
& \left(H^{*}+\frac{\partial s}{\partial t}+\left(\left(\frac{\partial s}{\partial t}\right)_{*}-g^{*}(t)\right)^{\prime} \varphi(t)\right)_{t_{f}}=0
\end{aligned}
$$

- Waktu akhir belum ditentukan dan state akhir belum ditentukan, tapi nilainya tidak bergantung pada sesuatu

$$
\begin{aligned}
& \gamma x\left(t_{0}\right)=x_{0} \\
& \left(H^{*}+\frac{\partial s}{\partial t}\right)_{t_{f}}=0,\left(\left(\frac{\partial s}{\partial t}\right)_{*}-g^{*}(t)\right)_{t_{f}}=0
\end{aligned}
$$

5. Untuk memperoleh kendali optimal, substitusikan solusi $x^{*}(t), g^{*}(t)$ dari langkah 4 ke dalam ekspresi optimal $u^{*}$ kendali pada langkah 2 .

\section{METODOLOGI PENELITIAN}

Langkah-langkah analisis yang akan dilakukan berdasarkan tujuan dalam penelitian ini adalah sebagai berikut:

1. Model penyebaran virus HIV.

2. Analisis sistem model penyebaran virus HIV.

a. Mencari titik setimbang dari sistem model penyebaran virus HIV.

b. Melakukan linearisasi dengan matriks jacobi

c. Menganalisis kestabilan sistem di sekitar titik setimbang.

d. Menganalisis keterkontrolan.

3. Menyusun fungsi tujuan dan memperoleh kendali optimal menggunakan Prinsip Maksimum Pontryagin.

4. Melakukan simulasi menggunakan MATLAB 2013a.

a. Menganalisis hasil simulasi sebelum diberi kontrol

b. Menganalisis hasil simulasi setelah diberi kontrol

c. Menarik kesimpulan dari hasil simulasi.

5. Menarik kesimpulan dari hasil penelitian yang telah diperoleh

\section{HASIL DAN PEMBAHASAN}

\section{A.Model Penyebaran Virus HIV}

Model matematika dikonstruksi berdasarkan pada interaksi antara sel $C D 4^{+} T$ yang tidak terinfeksi $x(t)$, sel $C D 4^{+} T$ yang terinfeksi $y(t)$, virus $v(t)$ dan kedua komponen dari respon imun yang diperoleh yaitu sel sitotoksik (CTL) $C(t)$ dan antibodi $A(t)$. Dengan mengasumsikan bahwa penyebaran virus terjadi dalam tubuh, sel sitotoksik terstimulasi karena adanya sel yang terinfeksi virus pada tingkat $\alpha_{1}$ serta respon dalam menghadapi sel terinfeksi pada tingkat $\mu_{1}$ dan antibodi terstimulasi karena adanya virus bebas pada tingkat $\mu_{2}$. Dalam model penyebaran virus HIV tersebut terdapat beberapa hal yang dapat menambah jumlah sel $C D 4^{+} T$ tidak terinfeksi yaitu masuknya sel $C D 4^{+} T$ pada tingkat $\omega$ dan perkembangbiakan sel pada tingkat $r x\left(1-\frac{x}{x_{m}}\right)$. Dan jumlah sel $C D 4^{+} T$ tidak terinfeksi dapat berkurang karena kematian pada tingkat $\omega_{0}$ dan terinfeksi virus $(\beta x v)$ dengan tingkat infeksi $\beta$ adalah konstan, sehingga dapat menambah jumlah sel $C D 4^{+} T$ tidak terinfeksi. Jumlah sel $C D 4^{+} T$ terinfeksi dapat berkurang karena keefektifan sel sitotoksik dalam membunuh sel $C D 4^{+} T$ terinfeksi pada tingkat $k_{1}$ dan matinya sel pada tingkat $\delta_{0}$, yang akan menghasilkan virus baru pada tingkat $N \delta_{0} y$ melalui proses lisis. Jumlah virus bebas dapat berkurang karena keefektifan antibodi dalam membunuh virus pada tingkat $k_{2}$ dan kematian pada tingkat $\delta_{1}$. Jumlah sel sitotoksik dan antibodi dapat berkurang karena habisnya sel sitotoksik pada tingkat $\mu_{10}$ dan habisnya antibodi pada tingkat $\mu_{20}$.

Dengan menggabungkan semua permasalahan yang dapat menyebabkan penyebaran virus HIV terjadi, didapatkan hasil persamaan yang disebut dengan model Preety Dubey dkk dengan persamaan sebagai berikut [1]:

$$
\begin{aligned}
& \dot{x}=\omega+r x\left(1-\frac{x}{x_{m}}\right)-\omega_{0} x-\beta\left(1-\eta_{r}\right) x v \\
& \dot{y}=\beta\left(1-\eta_{r}\right) x v-\delta_{0} y-k_{1} C y \\
& \dot{v}=N \delta_{0}\left(1-\eta_{P}\right) y-\delta_{1} v-k_{2} A v \\
& \dot{C}=\alpha_{1} y+\mu_{1} C y-\mu_{10} C \\
& \dot{A}=\mu_{2} v A-\mu_{20} A \\
& \quad x(0)>0, \quad y(0) \geq 0, v(0) \geq 0, C(0) \geq 0, A(0) \geq 0 .
\end{aligned}
$$

\section{B. Analisis Sistem Model Penyebaran Virus HIV}

Keadaan setimbang merupakan kondisi dimana perubahan jumlah populasi sepanjang waktu adalah 0. Berdasarkan Definisi (1), model penyebaran virus HIV dikatakan setimbang jika $\dot{x}=\dot{y}=\dot{v}=\dot{C}=\dot{A}=0$ sehingga

diperoleh tiga titik setimbang yaitu:

a. Titik setimbang non endemik, $E_{0}\left(x_{a}, 0,0,0,0\right)$

$$
E_{0}\left(\frac{x_{m}}{2 r}\left[\left(r-\omega_{0}\right)+\sqrt{\frac{4 r}{x_{m}} \lambda+\left(r-\omega_{0}\right)^{2}}\right], 0,0,0,0\right)
$$

b. Titik setimbang bebas imun, $E_{1}\left(x^{*}, y^{*}, v^{*}, 0,0\right)$

$$
\begin{aligned}
& E_{1}\left(\frac{\delta_{1}}{\beta N\left(1-\eta_{r}\right)\left(1-\eta_{P}\right)},\right. \\
& \frac{1}{\delta_{0}}\left(\omega+\left(r-\omega_{0}\right) \frac{\delta_{1}}{\beta N\left(1-\eta_{r}\right)\left(1-\eta_{P}\right)}\right. \\
& \left.-\frac{r}{x_{m}}\left(\frac{\delta_{1}}{\beta N\left(1-\eta_{r}\right)\left(1-\eta_{P}\right)}\right)^{2}\right),\left(\frac{N \delta_{0}\left(1-\eta_{P}\right)}{\delta_{1}}\right) \frac{1}{\delta_{0}}(\omega \\
& +\left(r-\omega_{0}\right) \frac{\delta_{1}}{\beta N\left(1-\eta_{r}\right)\left(1-\eta_{P}\right)} \\
& \left.\left.-\frac{r}{x_{m}}\left(\frac{\delta_{1}}{\beta N\left(1-\eta_{r}\right)\left(1-\eta_{P}\right)}\right)^{2}\right), 0,0,0\right)
\end{aligned}
$$

Setelah diperoleh titik setimbang dari sistem dinamik model penyebaran virus HIV, langkah selanjutnya adalah menganalisis kestabilan dari sistem tersebut. Berdasarkan persamaan (10) - (14) terlihat bahwa model matematika penyebaran virus HIV merupakan sistem PD autonomous yang tak linear, maka untuk mendapatkan kestabilan akan dilakukan linierisasi dengan menggunakan matriks Jacobi.

Persamaan (10) - (14) dapat dinyatakan sebagai fungsi dari variabel $x, y, v, C$ dan $A$, sehingga persamaan tersebut dapat dinyatakan secara umum sebagai berikut :

$$
\begin{aligned}
& \dot{x}=\omega+r x\left(1-\frac{x}{x_{m}}\right)-\omega_{0} x-\beta\left(1-\eta_{r}\right) x v=f_{1}(x, y, v, C, A) \\
& \dot{y}=\beta\left(1-\eta_{r}\right) x v-\delta_{0} y-k_{1} C y=f_{2}(x, y, v, C, A) \\
& \dot{v}=N \delta_{0}\left(1-\eta_{P}\right) y-\delta_{1} v-k_{2} A v=f_{3}(x, y, v, C, A) \\
& \dot{C}=\alpha_{1} y+\mu_{1} C y-\mu_{10} C=f_{4}(x, y, v, C, A) \\
& \dot{A}=\mu_{2} v A-\mu_{20} A=f_{5}(x, y, v, C, A)
\end{aligned}
$$


c. Titik setimbang endemik, $E_{2}(\bar{x}, \bar{y}, \bar{v}, \bar{C}, \bar{A})$

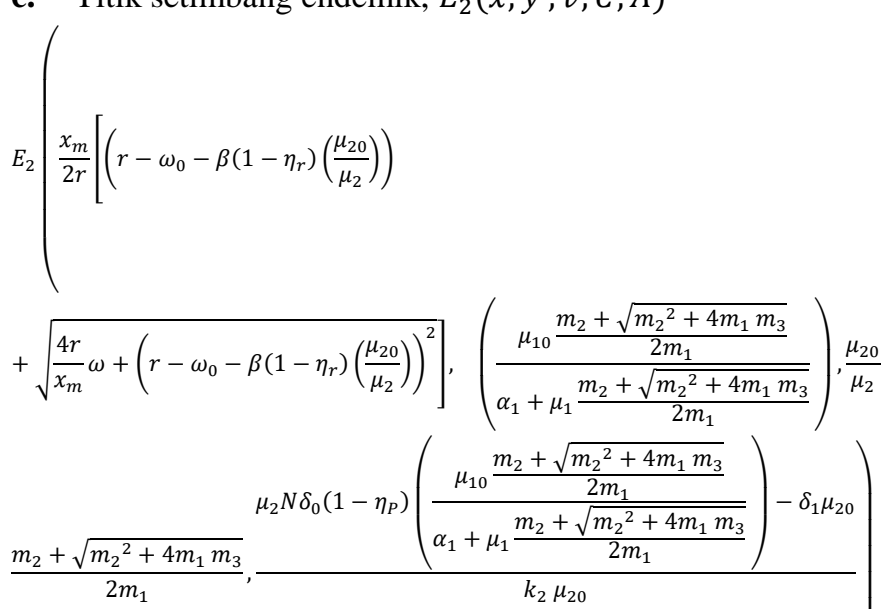

berdasarkan Definisi (2), maka matriks Jacobian dari persamaan (6) - (10) adalah:

$J=\left(\begin{array}{ccccc}-Z_{1} & 0 & -\beta\left(1-\eta_{r}\right) x & 0 & 0 \\ \beta\left(1-\eta_{r}\right) v & -Z_{2} & \beta\left(1-\eta_{r}\right) x & -k_{1} y & 0 \\ 0 & N \delta_{0}\left(1-\eta_{P}\right) & -Z_{3} & 0 & -k_{2} v \\ 0 & \alpha_{1}+\mu_{1} C & 0 & -Z_{4} & 0 \\ 0 & 0 & \mu_{2} A & 0 & -Z_{5}\end{array}\right)$ dengan $Z_{1}=\frac{2 r x}{x_{m}}+\omega_{0}+\beta\left(1-\eta_{r}\right) v-r, Z_{2}=\delta_{0}+k_{1} C$, $Z_{3}=\delta_{1}+k_{2} A, \quad Z_{4}=\mu_{10}-\mu_{1} y, \quad Z_{5}=\mu_{20}-\mu_{2} v$.

1) Kestabilan lokal titik setimbang non endemik $E_{0}\left(x_{a}, 0,0,0,0\right)$

$J\left(E_{0}\right)=\left(\begin{array}{ccccc}-Z_{1} & 0 & -\beta\left(1-\eta_{r}\right) x_{a} & 0 & 0 \\ 0 & -\delta_{0} & \beta\left(1-\eta_{r}\right) x_{a} & 0 & 0 \\ 0 & N \delta_{0}\left(1-\eta_{P}\right) & -\delta_{1} & 0 & 0 \\ 0 & \alpha_{1} & 0 & -\mu_{10} & 0 \\ 0 & 0 & 0 & 0 & -\mu_{20}\end{array}\right)$ dengan $Z_{1}=\frac{2 r x_{a}}{x_{m}}+\omega_{0}-r$.

Persamaan karakteristik dari matriks Jacobian tersebut dapat dicari dengan menggunakan $\left|\lambda I-J\left(E_{0}\right)\right|=0$, sehingga diperoleh :

$\left(\lambda+\mu_{20}\right)\left(\lambda+\mu_{10}\right)\left(\lambda+Z_{1}\right)\left(\lambda^{2}+b \lambda+c\right)=0$ dengan $b=\delta_{0}+\delta_{1}$ dan $c=\delta_{0} \delta_{1}-\beta x_{a} N \delta_{0}\left(1-\eta_{P}\right)\left(1-\eta_{r}\right)$ dan diperoleh nilai eigen dari matriks $J\left(E_{0}\right)$ adalah

$\lambda_{1}=-\mu_{20}$

$\lambda_{2}=-\mu_{10}$

$\lambda_{3}=-Z_{1}=-\left(\frac{2 r x_{a}}{x_{m}}+\omega_{0}-r\right)$ dan

$\lambda_{4,5}=\frac{-b \pm \sqrt{b^{2}-4 a c}}{2 a}$

$=\frac{-\left(\delta_{0}+\delta_{1}\right) \pm \sqrt{\left(\delta_{0}+\delta_{1}\right)^{2}-4\left(\delta_{0} \delta_{1}-\beta x_{a} N \delta_{0}\left(1-\eta_{P}\right)\left(1-\eta_{r}\right)\right)}}{2}$

Berdasarkan Definisi 4, dapat dilihat dari persamaan karakteristik tersebut bahwa nilai eigen $\lambda_{1}, \lambda_{2}, \lambda_{3}, \lambda_{4}<0$ karena semua parameter bernilai positif dan $\lambda_{5}<0$ jika $\frac{\beta x_{a} N\left(1-\eta_{P}\right)\left(1-\eta_{r}\right)}{\delta_{1}}<1$

Jadi dapat disimpulkan bahwa titik setimbang non endemik stabil jika $\frac{\beta x_{a} N\left(1-\eta_{P}\right)\left(1-\eta_{r}\right)}{\delta_{1}}<1$ atau dapat ditulis $R_{0}<1$. Hal ini merepresentasikan bahwa pada awal infeksi jika $R_{0}<1$ (jumlah infeksi baru rata-rata kurang dari 1) maka infeksi tidak akan meningkat dan sistem akan menjadi bebas penyakit.

2) Kestabilan lokal titik setimbang bebas imun $E_{1}\left(x^{*}, y^{*}, v^{*}, 0,0\right)$

$J\left(E_{1}\right)=\left(\begin{array}{ccccc}-Z_{1} & 0 & -\beta\left(1-\eta_{r}\right) x^{*} & 0 & 0 \\ \beta\left(1-\eta_{r}\right) v^{*} & -\delta_{0} & \beta\left(1-\eta_{r}\right) x^{*} & -k_{1} y^{*} & 0 \\ 0 & N \delta_{0}\left(1-\eta_{P}\right) & -\delta_{1} & 0 & -k_{2} v^{*} \\ 0 & \alpha_{1} & 0 & -Z_{2} & 0 \\ 0 & 0 & 0 & 0 & -Z_{3}\end{array}\right)$

dengan $Z_{1}=\frac{2 r x^{*}}{x_{m}}+\omega_{0}+\beta\left(1-\eta_{r}\right) v^{*}-r$

$Z_{2}=\mu_{10}-\mu_{1} y^{*}, Z_{3}=\mu_{20}-\mu_{2} v^{*}$.

Persamaan karakteristik dari matriks Jacobian tersebut dapat dicari dengan menggunakan $\left|\lambda I-J\left(E_{1}\right)\right|=0$, sehingga diperoleh :

$$
\begin{aligned}
& \left(\lambda+Z_{3}\right)\left(\lambda^{4}+\lambda^{3} n_{1}+\lambda^{2} n_{2}+\lambda n_{3}+n_{4}\right)=0 \\
\text { dengan } & \\
n_{1}= & Z_{1}+\delta_{0}+\delta_{1}+Z_{2} \\
n_{2}= & Z_{2}\left(Z_{1}+\delta_{0}+\delta_{1}\right)+Z_{1} \delta_{0}+\delta_{1}\left(Z_{1}+\delta_{0}\right)+k_{1} y^{*} \alpha_{1}- \\
& \beta x^{*} N \delta_{0}\left(1-\eta_{P}\right)\left(1-\eta_{r}\right) \\
n_{3}= & Z_{2}\left(Z_{1} \delta_{0}+\delta_{1}\left(Z_{1}+\delta_{0}\right)-\beta x^{*} N \delta_{0}\left(1-\eta_{P}\right)(1-\right. \\
& \left.\left.\eta_{r}\right)\right)+\beta x^{*} N \delta_{0}\left(1-\eta_{P}\right)\left(1-\eta_{r}\right)\left(\beta\left(1-\eta_{r}\right) v^{*}-\right. \\
& \left.Z_{1}\right)+k_{1} y^{*} \alpha_{1}\left(Z_{1}+\delta_{1}\right)+Z_{1} \delta_{0} \delta_{1} \\
n_{4}= & Z_{2}\left(Z_{1} \delta_{0} \delta_{1}+\beta x^{*} N \delta_{0}\left(1-\eta_{P}\right)\left(1-\eta_{r}\right)(\beta(1-\right. \\
& \left.\left.\left.\eta_{r}\right) v^{*}-Z_{1}\right)\right)+k_{1} y^{*} \alpha_{1} Z_{1} \delta_{1}
\end{aligned}
$$

Berdasarkan Definisi 4, dapat dilihat dari persamaan karakteristik tersebut bahwa nilai eigen $\lambda_{1}<0$ dengan syarat $\mu_{2} v^{*}<\mu_{20}$. Selanjutnya akan dicari kestabilan dari persamaan $\left(\lambda^{4}+\lambda^{3} n_{1}+\lambda^{2} n_{2}+\lambda n_{3}+n_{4}\right)=0$ menggunakan kriteria Routh-Hurwitz.

Perhitungan kriteria Routh-Hurwitz

$$
\begin{array}{cccccc}
s^{4} & 1 & n_{2} & n_{4} & 0 & 0 \\
s^{3} & \frac{n_{1} n_{2}-n_{3}}{n_{1}} & n_{3} & 0 & 0 & \\
s^{2} & \frac{n_{4}}{n_{1}} & 0 & & \\
s^{1} & \frac{n_{1} n_{2} n_{3}-n_{3}{ }^{2}-n_{1}{ }^{2} n_{4}}{n_{1} n_{2}-n_{3}} & 0 & & \\
s^{0} & n_{4} & & &
\end{array}
$$

Berdasarkan kriteria Routh-Hurwitz, persamaan $\left(\lambda^{4}+\right.$ $\left.\lambda^{3} n_{1}+\lambda^{2} n_{2}+\lambda n_{3}+n_{4}\right)=0 \quad$ stabil jika $n_{1}, n_{4}>0$, $n_{1} n_{2}>n_{3}$ dan $n_{1} n_{2} n_{3}>n_{3}{ }^{2}+n_{1}{ }^{2} n_{4}$.

Dari uraian di atas dapat disimpulkan bahwa titik setimbang bebas imun stabil jika $\mu_{2} v^{*}<\mu_{20}, n_{1}, n_{4}>0$, $n_{1} n_{2}>n_{3}$ dan $n_{1} n_{2} n_{3}>n_{3}{ }^{2}+n_{1}{ }^{2} n_{4}$. Hal ini merepresentasikan bahwa dengan tidak adanya respon imun, infeksi berlanjut di zona endemik dalam keadaan stabil di bawah kondisi $\mu_{2} v^{*}<\mu_{20}, n_{1}, n_{4}>0, n_{1} n_{2}>n_{3}$ dan $n_{1} n_{2} n_{3}>n_{3}^{2}+n_{1}^{2} n_{4}$.

3) Kestabilan lokal titik setimbang endemik $E_{2}(\bar{x}, \bar{y}, \bar{v}, \bar{C}, \bar{A})$

$$
J E_{2}=\left(\begin{array}{ccccc}
-Z_{1} & 0 & -\beta\left(1-\eta_{r}\right) \bar{x} & 0 & 0 \\
\beta\left(1-\eta_{r}\right) \bar{v} & -Z_{2} & \beta\left(1-\eta_{r}\right) \bar{x} & -k_{1} \bar{y} & 0 \\
0 & N \delta_{0}\left(1-\eta_{P}\right) & -Z_{3} & 0 & -k_{2} \bar{v} \\
0 & \alpha_{1}+\mu_{1} \bar{C} & 0 & -Z_{4} & 0 \\
0 & 0 & \mu_{2} \bar{A} & 0 & 0
\end{array}\right)
$$
dengan $Z_{1}=\frac{2 r \bar{x}}{x_{m}}+\omega_{0}+\beta\left(1-\eta_{r}\right) \bar{v}-r, Z_{2}=\delta_{0}+k_{1} \bar{C}$, $Z_{3}=\delta_{1}+k_{2} \bar{A}, \quad Z_{4}=\mu_{10}-\mu_{1} \bar{y}$.

Persamaan karakteristik dari matriks Jacobian tersebut dapat dicari dengan menggunakan $\left|\lambda I-J E_{2}\right|=0$, sehingga diperoleh :

$\left(\lambda^{5}+\lambda^{4} s_{1}+\lambda^{3} s_{2}+\lambda^{3} s_{3}+\lambda s_{4}+s_{5}\right)=0$ 
dengan

$$
\begin{aligned}
s_{1}= & Z_{1}+Z_{2}+Z_{3}+Z_{4} \\
s_{2}= & Z_{4}\left(Z_{1}+Z_{2}+Z_{3}\right)+Z_{1} Z_{2}+Z_{3}\left(Z_{1}+Z_{2}\right)+k_{1} \bar{y}\left(\alpha_{1}+\right. \\
& \left.\mu_{1} \bar{C}\right)-\beta \bar{x} N \delta_{0}\left(1-\eta_{P}\right)\left(1-\eta_{r}\right)+k_{2} \bar{v} \mu_{2} \bar{A} \\
s_{3}= & Z_{4}\left(Z_{1} Z_{2}+Z_{4}\left(Z_{1}+Z_{2}\right)-\beta \bar{x} N \delta_{0}\left(1-\eta_{P}\right)\left(1-\eta_{r}\right)\right) \\
& +\beta \bar{x} N \delta_{0}\left(1-\eta_{P}\right)\left(1-\eta_{r}\right)\left(\beta\left(1-\eta_{r}\right) \bar{v}-Z_{1}\right) \\
& +k_{1} \bar{y}\left(\alpha_{1}+\mu_{1} \bar{C}\right)\left(Z_{1}+Z_{3}\right)+Z_{1} Z_{2} Z_{3} \\
& +k_{2} \bar{v} \mu_{2} \bar{A}\left(Z_{1}+Z_{2}+Z_{4}\right) \\
s_{4}= & Z_{4}\left(Z_{1} Z_{2} Z_{3}+\beta \bar{x} N \delta_{0}\left(1-\eta_{P}\right)\left(1-\eta_{r}\right)\left(\beta\left(1-\eta_{r}\right) \bar{v}-Z_{1}\right)\right) \\
& +k_{1} \bar{y}\left(\alpha_{1}+\mu_{1} \bar{C}\right) Z_{1} Z_{3} \\
& +k_{2} \bar{v} \mu_{2} \bar{A}\left(Z_{1} Z_{4}+Z_{1} Z_{2}+Z_{2} Z_{4}+k_{1} \bar{y}\left(\alpha_{1}+\mu_{1} \bar{C}\right)\right) \\
s_{5}= & Z_{1} k_{2} \bar{v} \mu_{2} \bar{A}\left(Z_{2} Z_{4}+k_{1} \bar{y}\left(\alpha_{1}+\mu_{1} \bar{C}\right)\right)
\end{aligned}
$$

Akan dicari kestabilan dari persamaan (20) menggunakan kriteria Routh-Hurwitz.

Perhitungan kriteria Routh-Hurwitz dari persamaan (20)

$$
\begin{aligned}
& \begin{array}{lllllll}
s^{5} & 1 & s_{2} & s_{4} & 0 & 0 & 0
\end{array} \\
& \begin{array}{llllll}
s^{4} & s_{1} & s_{3} & s_{5} & 0 & 0
\end{array}
\end{aligned}
$$

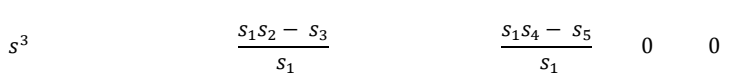

$$
\begin{aligned}
& s^{2} \quad \frac{s_{1} s_{2} s_{3}-s_{3}{ }^{2}-s_{1}{ }^{2} s_{4}+s_{1} s_{5}}{s_{1} s_{2}-s_{3}} \quad s_{5} \quad 0 \\
& s^{1} \quad \frac{\left(s_{1} s_{4}-s_{5}\right)}{s_{1}}-\frac{s_{5}\left(s_{1} s_{2}-s_{3}\right)^{2}}{s_{1}\left(s_{1} s_{2} s_{3}-s_{3}^{2}-s_{1}^{2} s_{4}+s_{1} s_{5}\right)} \quad 0
\end{aligned}
$$

Berdasarkan kriteria Routh-Hurwitz, persamaan (20) stabil jika $s_{1}, s_{5}>0, s_{1} s_{2}>s_{3}, s_{1} s_{2} s_{3}+s_{1} s_{5}>{s_{1}}^{2} s_{4}+{s_{3}}^{2}$, dan $s_{1} s_{4}>s_{5}+s_{5}\left(s_{1} s_{2}-s_{3}\right)^{2}$.

Dari uraian di atas dapat disimpulkan bahwa titik setimbang endemik stabil jika $s_{1}, s_{5}>0, s_{1} s_{2}>s_{3}, s_{1} s_{2} s_{3}+s_{1} s_{5}>$ $s_{1}{ }^{2} s_{4}+s_{3}{ }^{2}$, dan $s_{1} s_{4}>s_{5}+s_{5}\left(s_{1} s_{2}-s_{3}\right)^{2}$. Hal ini merepresentasikan bahwa jumlah sel-sel $C D 4^{+} T$ yang tidak terinfeksi dengan adanya respon imun lebih besar daripada tidak adanya respon imun. Begitu juga dengan sel $C D 4^{+} T$ yang tidak terinfeksi dalam kasus titik setimbang bebas virus ketika tidak ada infeksi di dalam tubuh.

Selanjutnya, akan dilakukan analisis keterkontrolan, dengan matriks $\bar{A}$ diperoleh dari sistem yang telah dilinierkan menggunakan matriks Jacobi yaitu

$$
\bar{A}=\left[\begin{array}{ccccc}
-Z_{1} & 0 & -\beta\left(1-\eta_{r}\right) x & 0 & 0 \\
\beta\left(1-\eta_{r}\right) v & -Z_{2} & \beta\left(1-\eta_{r}\right) x & -k_{1} y & 0 \\
0 & N \delta_{0}\left(1-\eta_{P}\right) & -Z_{3} & 0 & -k_{2} v \\
0 & \alpha_{1}+\mu_{1} C & 0 & -Z_{4} & 0 \\
0 & 0 & \mu_{2} A & 0 & -Z_{5}
\end{array}\right]
$$

dengan

$$
\begin{aligned}
Z_{1} & =\frac{2 r x}{x_{m}}+\omega_{0}+\beta\left(1-\eta_{r}\right) v-r \\
Z_{2} & =\delta_{0}+k_{1} C, \\
Z_{3} & =\delta_{1}+k_{2} A \\
Z_{4} & =\mu_{10}-\mu_{1} y \\
Z_{5} & =\mu_{20}-\mu_{2} v
\end{aligned}
$$

dan matriks $\bar{B}$ diperoleh:

$$
\bar{B}=\left[\begin{array}{cc}
\beta x v & 0 \\
-\beta x v & 0 \\
0 & -N \delta_{0} y \\
0 & 0 \\
0 & 0
\end{array}\right]
$$

Berdasarkan Teorema 6 dapat disusun matriks keterkontrolan $\left(M_{C}\right)$ sebagai berikut :

$$
\left(M_{c}\right)=\left(\bar{B}|\overline{A B}| \overline{A^{2} B}\left|\overline{A^{3} B}\right| \overline{A^{4} B}\right)
$$

dan diperoleh matriks $M_{C}$ keterkontrolan seperti berikut :
$M_{C}=\left[\begin{array}{cc|cc|cc|cc|cc}\beta x v & 0 & c_{1} & c_{2} & d_{1} & d_{2} & e_{1} & e_{2} & f_{1} & f_{2} \\ -\beta x v & 0 & c_{3} & -c_{2} & d_{3} & d_{4} & e_{3} & e_{4} & f_{3} & f_{4} \\ 0 & -N \delta_{0} y & c_{4} & c_{5} & d_{5} & d_{6} & e_{5} & e_{6} & f_{5} & f_{6} \\ 0 & 0 & c_{6} & 0 & d_{7} & d_{8} & e_{7} & e_{8} & f_{7} & f_{8} \\ 0 & 0 & 0 & c_{7} & d_{9} & d_{10} & e_{9} & e_{10} & f_{9} & f_{10}\end{array}\right]$

dimana,

$$
\begin{aligned}
& c_{1}=-Z_{1}(\beta x v) \\
& c_{2}=\beta x\left(1-\eta_{r}\right) N \delta_{0} y \\
& c_{3}=\left(\beta\left(1-\eta_{r}\right) v+Z_{2}\right)(\beta x v) \\
& c_{4}=-N \delta_{0}\left(1-\eta_{P}\right) \beta x v \\
& c_{5}=Z_{3} N \delta_{0} y \\
& c_{6}=-\left(\alpha_{1}+\mu_{1} C\right) \beta x v \\
& c_{7}=-\mu_{2} A N \delta_{0} y \\
& d_{1}=-Z_{1} c_{1}-\beta x\left(1-\eta_{r}\right) c_{4} \\
& d_{2}=-Z_{1} c_{2}-\beta x\left(1-\eta_{r}\right) c_{5} \\
& d_{3}=\beta v\left(1-\eta_{r}\right) c_{1}-Z_{2} c_{3}+\beta x\left(1-\eta_{r}\right) c_{4}-k_{1} y c_{6} \\
& d_{4}=\left(\beta v\left(1-\eta_{r}\right)+Z_{2}\right) c_{2}+\beta x\left(1-\eta_{r}\right) c_{5} \\
& d_{5}=N \delta_{0}\left(1-\eta_{P}\right) c_{3}-Z_{3} c_{4} \\
& d_{6}=-N \delta_{0}\left(1-\eta_{P}\right) c_{2}-Z_{3} c_{5}-k_{2} v c_{7} \\
& d_{7}=\left(\alpha_{1}+\mu_{1} C\right) c_{3}-Z_{4} c_{6} \\
& d_{8}=-\left(\alpha_{1}+\mu_{1} C\right) c_{2} \\
& d_{9}=\mu_{2} A c_{4} \\
& d_{10}=\mu_{2} A c_{5}-Z_{5} c_{7} \\
& e_{1}=-Z_{1} d_{1}-\beta x\left(1-\eta_{r}\right) d_{5} \\
& e_{2}=-Z_{1} d_{2}-\beta x\left(1-\eta_{r}\right) d_{6} \\
& e_{3}=\beta v\left(1-\eta_{r}\right) d_{1}-Z_{2} d_{3}+\beta x\left(1-\eta_{r}\right) d_{5}-k_{1} y d_{7} \\
& e_{4}=\beta v\left(1-\eta_{r}\right) d_{2}-Z_{2} d_{4}+\beta x\left(1-\eta_{r}\right) d_{6}-k_{1} y d_{8} \\
& e_{5}=N \delta_{0}\left(1-\eta_{P}\right) d_{3}-Z_{3} d_{5}-k_{2} v d_{9} \\
& e_{6}=N \delta_{0}\left(1-\eta_{P}\right) d_{4}-Z_{3} d_{6}-k_{2} v d_{10} \\
& e_{7}=\left(\alpha_{1}+\mu_{1} C\right) d_{3}-Z_{4} d_{7} \\
& e_{8}=\left(\alpha_{1}+\mu_{1} C\right) d_{4}-Z_{4} d_{8} \\
& e_{9}=\mu_{2} A d_{5}-Z_{5} d_{9} \\
& e_{10}=\mu_{2} A d_{6}-Z_{5} d_{10} \\
& f_{1}=-Z_{1} e_{1}-\beta x\left(1-\eta_{r}\right) e_{5} \\
& f_{2}=-Z_{1} e_{2}-\beta x\left(1-\eta_{r}\right) e_{6} \\
& f_{3}=\beta v\left(1-\eta_{r}\right) e_{1}-Z_{2} e_{3}+\beta x\left(1-\eta_{r}\right) e_{5}-k_{1} y e_{7} \\
& f_{4}=\beta v\left(1-\eta_{r}\right) e_{2}-Z_{2} e_{4}+\beta x\left(1-\eta_{r}\right) e_{6}-k_{1} y e_{8} \\
& f_{5}=N \delta_{0}\left(1-\eta_{P}\right) e_{3}-Z_{3} e_{5}-k_{2} v e_{9} \\
& f_{6}=N \delta_{0}\left(1-\eta_{P}\right) e_{4}-Z_{3} e_{6}-k_{2} v e_{10} \\
& f_{7}=\left(\alpha_{1}+\mu_{1} C\right) e_{3}-Z_{4} e_{7} \\
& f_{8}=\left(\alpha_{1}+\mu_{1} C\right) e_{4}-Z_{4} e_{8} \\
& f_{9}=\mu_{2} A e_{5}-Z_{5} e_{9} \\
& f_{10}=\mu_{2} A e_{6}-Z_{5} e_{10} \\
& \quad D=n g a n d \\
&
\end{aligned}
$$

Dengan didapatkannya matriks keterkontrolan diatas dapat diamati bahwa rank $M_{C}=5$, dengan demikian sistem dinamik dari penyebaran penyakit HIV bersifat terkontrol.

\section{Kontrol Optimal Penyebaran Virus HIV}

Teori kontrol optimal akan digunakan untuk menganalisis perilaku model penyebaran virus HIV setelah diberi kontrol (terapi antiretroviral). Masalah kontrol optimal untuk penyebaran virus HIV adalah menentukan fungsi kontrol yang optimal sedemikian sehingga jumlah sel $C D 4^{+} T$ meningkat. Didefinisikan fungsi tujuan sebagai berikut:

$J\left(\eta_{r}, \eta_{p}\right)=\int_{t 0}^{t f}\left(x(t)+C(t)+A(t)-\left(\frac{B_{1} \eta_{r}{ }^{2}}{2}+\frac{B_{2} \eta_{p}{ }^{2}}{2}\right)\right) d t$

Konstanta positif $B_{1}$ dan $B_{2}$ merupakan parameter bobot yang dikenakan pada kontrol, dan dimana kontrol $\eta_{r}$ mewakili efisiensi terapi obat RTI dalam menghambat infeksi baru. Kontrol $\eta_{p}$ mewakili efisiensi terapi obat PI dalam menghambat produksi virus. Jika $\eta_{p}, \eta_{r}=1$ 
penghambatannya $100 \%$ efektif namun ketika $\eta_{p}, \eta_{r}=0$ penghambatannya tidak ada. Tujuan dari penyelesaian kontrol optimal pada penelitian ini adalah untuk meningkatkan jumlah sel $C D 4^{+} T x(t)$, sel sitotoksik $C(t)$, dan antibodi $A(t)$ dengan meminimalkan biaya pengobatan terapi antiretroviral. Dengan demikian masalah kontrol optimal dapat dituliskan sebagai berikut:

$$
J\left(\eta_{r_{*}}, \eta_{p_{*}}\right)=\max J\left(\eta_{r}, \eta_{p}\right)
$$

Selanjutnya akan diperoleh kontrol optimal menggunakan Prinsip Maksimum Pontryagin dengan langkah-langkah sebagai berikut:

1. Bentuk fungsi Hamiltonian

$$
\begin{aligned}
& H=x(t)+C(t)+A(t)-\left(\frac{B_{1} \eta_{r}{ }^{2}}{2}+\frac{B_{2} \eta_{p}{ }^{2}}{2}\right) \\
& +g_{1}\left(\omega+r x\left(1-\frac{x}{x_{m}}\right)-\omega_{0} x-\beta\left(1-\eta_{r}\right) x v\right) \\
& +g_{2}\left(\beta\left(1-\eta_{r}\right) x v-\delta_{0} y-k_{1} C y\right) \\
& +g_{3}\left(N \delta_{0}\left(1-\eta_{P}\right) y-\delta_{1} v-k_{2} A v\right) \\
& +g_{4}\left(\alpha_{1} y+\mu_{1} C y-\mu_{10} C\right)+g_{5}\left(\mu_{2} v A-\mu_{20} A\right)
\end{aligned}
$$

2. Menentukan kondisi stasioner dari persamaan (21) untuk mendapatkan persamaan kontrol optimal, dan diperoleh

a. $\eta_{r}=\frac{\beta x v\left(g_{1}-g_{2}\right)}{B_{1}}$

Karena batasan nilai $\eta_{r}$ adalah $0<\eta_{r}<1$, maka diperoleh beberapa kemungkinan hasil yang di dapat yaitu

$$
\eta_{r}\left\{\begin{array}{cl}
\frac{\beta x v\left(g_{1}-g_{2}\right)}{B_{1}}, & j i k a 0<\frac{\beta x v\left(g_{1}-g_{2}\right)}{B_{1}}<1 \\
0, & j i k a \frac{\beta x v\left(g_{1}-g_{2}\right)}{B_{1}} \leq 0 \\
1, & j i k a \frac{\beta x v\left(g_{1}-g_{2}\right)}{B_{1}} \geq 1
\end{array}\right.
$$

Dari beberapa kemungkinan diatas, maka pengontrol yang optimal adalah

$$
\eta_{r}=\min \left\{\max \left\{0, \frac{\beta x v\left(g_{1}-g_{2}\right)}{B_{1}}\right\}, 1\right\}
$$

b. $\quad \eta_{p}=\frac{-N \delta_{0} y g_{3}}{B_{2}}$

Karena batasan nilai $\eta_{p}$ adalah $0<\eta_{p}<1$, maka diperoleh beberapa kemungkinan hasil yang di dapat yaitu

$$
\eta_{p}\left\{\begin{array}{cl}
\frac{-N \delta_{0} y g_{3}}{B_{2}}, & \text { jika } 0<\frac{-N \delta_{0} y g_{3}}{B_{2}}<1 \\
0, & j i k a \frac{-N \delta_{0} y g_{3}}{B_{2}} \leq 0 \\
1, & j i k a \frac{-N \delta_{0} y g_{3}}{B_{2}} \geq 1
\end{array}\right.
$$

Dari beberapa kemungkinan diatas, maka pengontrol yang optimal adalah

$$
\eta_{p}=\min \left\{\max \left\{0, \frac{-N \delta_{0} y g_{3}}{B_{2}}\right\}, 1\right\}
$$

3. Menentukan $H^{*}$ yang optimal

Dengan mensubtitusikan persamaan (22) dan (23) ke dalam persamaan (21) sehingga diperoleh:

$$
H^{*}=x(t)+C(t)+A(t)
$$

$$
-\left(\frac{\left(\beta x v\left(g_{1}-g_{2}\right)\right)^{2}}{2 B_{1}}+\frac{\left(N \delta_{0} y g_{3}\right)^{2}}{2 B_{2}}\right)
$$

$$
\begin{aligned}
& +g_{1}\left(\omega+r x\left(1-\frac{x}{x_{m}}\right)-\omega_{0} x\right. \\
& \left.-\beta\left(1-\frac{\beta x v\left(g_{1}-g_{2}\right)}{B_{1}}\right) x v\right) \\
& +g_{2}\left(\beta\left(1-\frac{\beta x v\left(g_{1}-g_{2}\right)}{B_{1}}\right) x v-\delta_{0} y-k_{1} C y\right) \\
& +g_{3}\left(N \delta_{0}\left(1+\frac{N \delta_{0} y g_{3}}{B_{2}}\right) y-\delta_{1} v-k_{2} A v\right) \\
& +g_{4}\left(\alpha_{1} y+\mu_{1} C y-\mu_{10} C\right)+g_{5}\left(\mu_{2} v A-\mu_{20} A\right)
\end{aligned}
$$

4. Menyelesaikan persamaan state dan costate untuk memperoleh sistem yang optimal

a. Persamaan State

$$
\begin{aligned}
& \frac{\partial H^{*}}{\partial g_{1}}=\omega+r x\left(1-\frac{x}{x_{m}}\right)-\omega_{0} x-\beta x v\left(1-\eta_{r}\right) \\
& \frac{\partial H^{*}}{\partial g_{2}}=\beta x v\left(1-\eta_{r}\right)-\delta_{0} y-k_{1} C y \\
& \frac{\partial H^{*}}{\partial g_{3}}=N \delta_{0} y\left(1-\eta_{p}\right)-\delta_{1} v-k_{2} A v \\
& \frac{\partial H^{*}}{\partial g_{4}}=\alpha_{1} y+\mu_{1} C y-\mu_{10} C \\
& \frac{\partial H^{*}}{\partial g_{5}}=\mu_{2} v A-\mu_{20} A
\end{aligned}
$$

b. Persamaan costate

$$
\begin{aligned}
\frac{\partial g_{1}}{\partial t} & =-\frac{\partial H^{*}}{\partial x} \\
& =-\left(1+\left(r-\frac{2 r x}{x_{m}}-\omega_{0}\right) g_{1}-\beta v\left(g_{1}-g_{2}\right)\left(1-\eta_{r}\right)\right) \\
\frac{\partial g_{2}}{\partial t} & \left.=-\frac{\partial H^{*}}{\partial y} \quad+\left(\alpha_{1}+\mu_{1} C\right) g_{4}\right) \\
& =-\left(N \delta_{0} g_{3}\left(1-\eta_{p}\right)-\left(\delta_{0}+k_{1} C\right) g_{2}\right. \\
\frac{\partial g_{3}}{\partial t} & \left.=-\frac{\partial H^{*}}{\partial v} \quad+\mu_{2} A g_{5}\right) \\
& =-\left(-\beta v\left(g_{1}-g_{2}\right)\left(1-\eta_{r}\right)-\left(\delta_{1}+k_{2} A\right) g_{3}\right. \\
\frac{\partial g_{4}}{\partial t} & =-\frac{\partial H^{*}}{\partial C} \quad+\left(1-k_{1} y g_{2}+\left(\mu_{1} y-\mu_{10}\right) g_{4}\right) \\
& =-\left(1 g^{*}\right. \\
\frac{\partial g_{5}}{\partial t} & =\frac{\partial A}{\partial A} \\
& =-\left(1-k_{2} v g_{3}+\left(\mu_{2} v-\mu_{20}\right) g_{5}\right)
\end{aligned}
$$

\section{D.Hasil Simulasi}

Pada sub bab ini akan dianalisis mengenai hasil simulasi yang membandingkan dinamika masing masing populasi sebelum dan setelah pemberian kendali optimal ke dalam sistem dengan model penyebaran virus HIV yang ditunjukkan melalui grafik, dengan menginputkan nilai nilai parameter yang disajikan dalam Tabel 1. Dengan menggunakan ODE45 pada MATLAB2013a, akan ditunjukkan kondisi sistem model penyebaran virus HIV sebelum dan setelah pemberian kendali optimal dalam grafik, dengan nilai awal $x(t)=50$, $y(t)=3, v(t)=50, C(t)=20$, dan $A(t)=30$ 


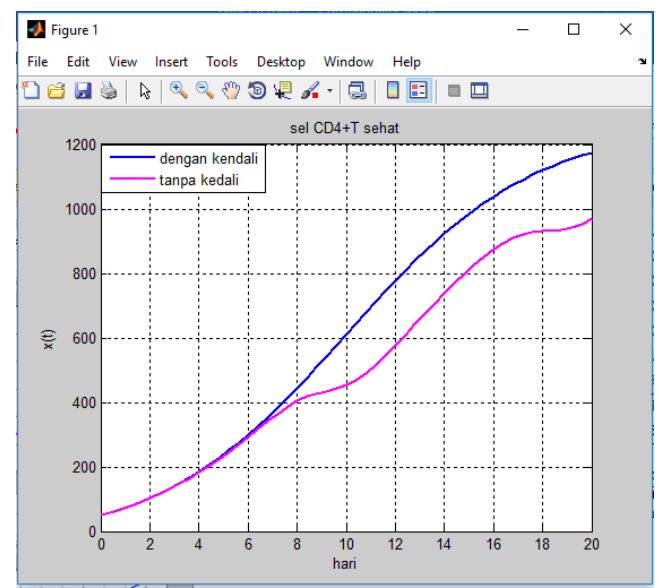

Gambar 1. Populasi sel $C D 4^{+} T$ tidak terinfeksi $x(t)$

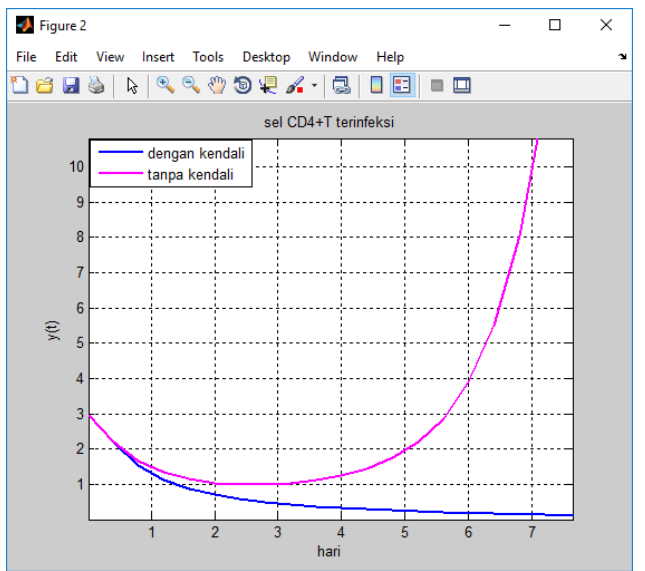

Gambar 2. Populasi sel $C D 4^{+} T$ terinfeksi $y(t)$

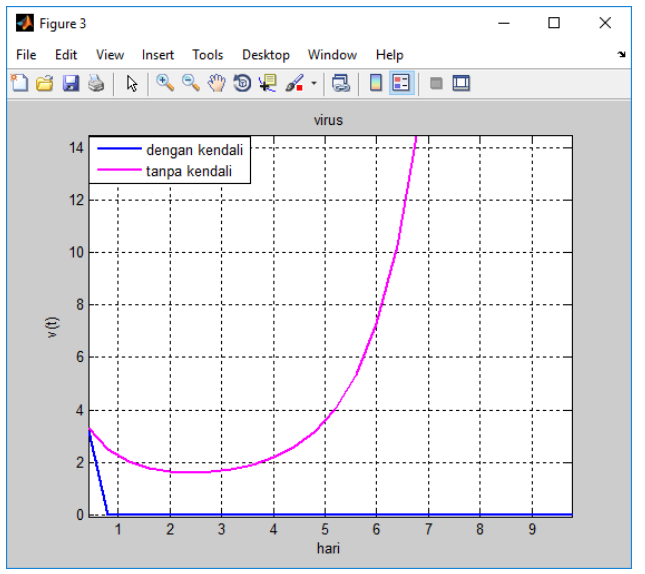

Gambar 3. Populasi virus HIV $v(t)$

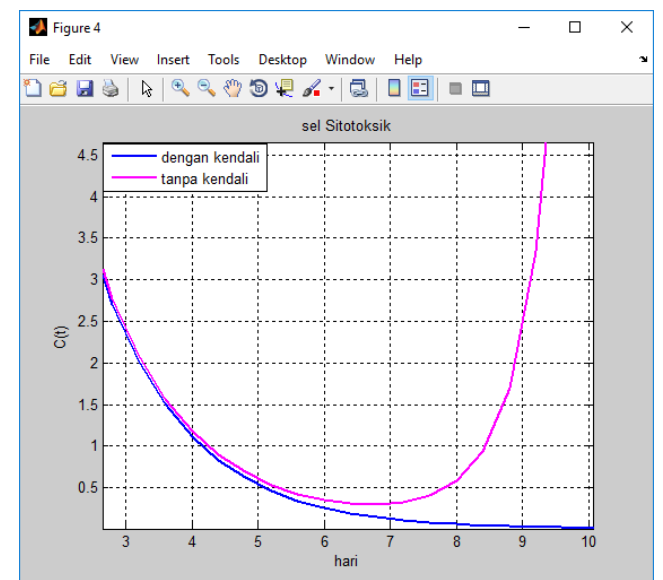

Gambar 4. Populasi sel sitotoksik $C(t)$

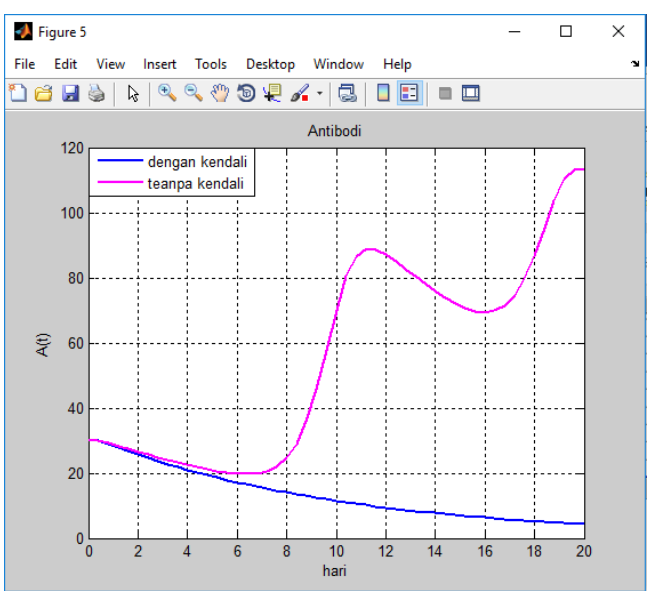

Gambar 5. Populasi Antibodi $A(t)$

Untuk simulasi ini, akan digunakan nilai parameter yang diberikan pada Tabel 1. Grafik dari simulasi model penyebaran virus HIV yang diberikan seperti gambar diatas dapat membantu membandingkan sel yang tidak terinfeksi, sel yang terinfeksi, virus HIV, sel sitotoksik dan antibodi sebelum dan sesudah pemberian kontrol berupa obat antiretroviral.

Gambar 1 menunjukkan bahwa setelah pemberian kontrol, populasi sel $C D 4^{+} T$ tidak terinfeksi tumbuh secara signifikan hingga 20\% yang meningkatkan kualitas hidup pasien. Pada Gambar 2, jumlah sel $C D 4^{+} T$ yang terinfeksi pada waktu akhir $\mathrm{tf}=20$ (hari) adalah 0,005 dalam kasus dengan kontrol dan 18,45 tanpa kontrol, dan total kasus dalam memblokir infeksi baru pada akhir program kontrol adalah 18,445, maka efisiensi terapi obat dalam memblokir infeksi baru adalah 99\%. Gambar 3 menunjukkan bahwa setelah diberi kontrol, virus HIV menurun ke nol. Jumlah virus bebas dengan kontrol pada waktu akhir adalah 0 dan tanpa kontrol berjumlah 8,1 , dan jumlah total dalam memblokir produksi virus pada akhir program kontrol adalah 8,1, maka efisiensi terapi obat dalam menghambat produksi virus bebas $100 \%$. Gambar 4 dan 5 menunjukkan bahwa respon imun yaitu sel sitotoksik dan antibodi ketika ada peningkatan infeksi maka akan diikuti oleh peningkatan respon imun, yang kemudian berfungsi untuk menghilangkan infeksi dengan membunuh sel yang terinfeksi dan virus dalam tubuh. Begitu infeksinya rendah, respon imun tidak diperlukan pada level yang tinggi dan inilah mengapa respon imun ikut turun.

Gambar 6 dan 7 yang diberikan dibawah ini menunjukkan kontrol optimal $\eta_{r}$ dan $\eta_{p}$ dalam memblokir infeksi baru dan menghambat produksi virus.

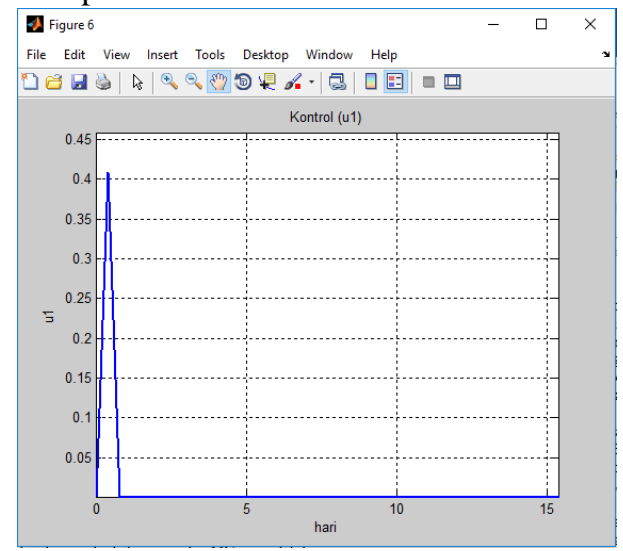

Gambar 6. Kontrol $\eta_{r}(t)$ 


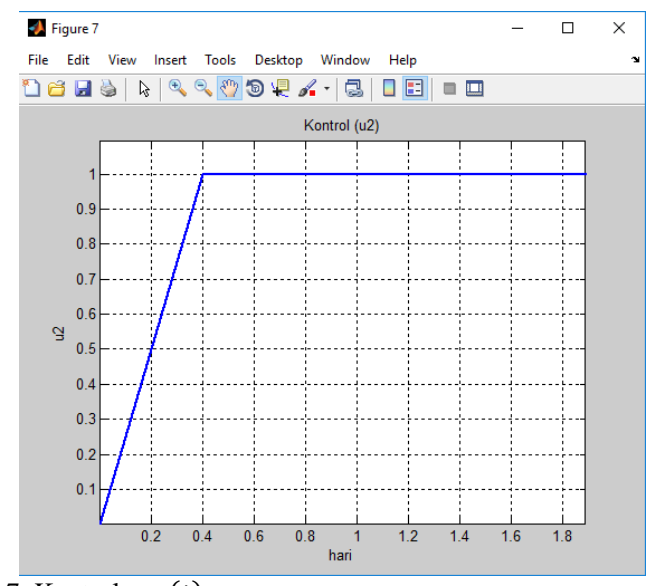

Gambar 7. Kontrol $\eta_{p}(t)$

\section{V.KESIMPULAN}

Dari hasil pembahasan yang telah disajikan pada bab sebelumnya, dapat disimpulkan bahwa:

1. Sistem dinamik pada model penyebaran virus HIV diperoleh 3 titik kesetimbangan yaitu:

a. Titik setimbang non endemik $E_{0}\left(x_{a}, 0,0,0,0\right)$, stabil asimtotis lokal jika $R_{0}=\frac{\beta x_{a} N\left(1-\eta_{P}\right)\left(1-\eta_{r}\right)}{\delta_{1}}<1$

b. Titik setimbang non endemik $E_{1}\left(x^{*}, y^{*}, v^{*}, 0,0\right)$, stabil asimtotis lokal jika $\mu_{2} v^{*}<\mu_{20}, n_{1}, n_{4}>0$, $n_{1} n_{2}>n_{3}$ dan $n_{1} n_{2} n_{3}>n_{3}{ }^{2}+n_{1}{ }^{2} n_{4}$,

c. Titik setimbang non endemik $E_{2}(\bar{x}, \bar{y}, \bar{v}, \bar{C}, \bar{A})$, stabil asimtotis lokal jika $s_{1}, s_{5}>0, s_{1} s_{2}>s_{3}, s_{1} s_{2} s_{3}+$ $s_{1} s_{5}>s_{1}{ }^{2} s_{4}+s_{3}{ }^{2}$, dan $s_{1} s_{4}>s_{5}+s_{5}\left(s_{1} s_{2}-\right.$ $\left.s_{3}\right)^{2}$.

2. Kendali optimal yang diperoleh pada upaya pemaksimalan atau peningkatan jumlah sel $C D 4^{+} T$ dengan menerapkan Prinsip Maksimum Pontryagin didapat pengendali berupa obat antiretroviral yaitu RTI $\left(\eta_{r}\right)$ yang akan optimal jika nilai $\eta_{r}=\frac{\beta x v\left(g_{1}-g_{2}\right)}{B_{1}}$ dan PI $\left(\eta_{p}\right)$ yang akan optimal jika nilai $\eta_{p}=\frac{-N \delta_{0} y g_{3}}{B_{2}}$.

3. Hasil simulasi sistem awal setelah pemberian kontrol dari model penyebaran virus HIV menunjukkan bahwa, populasi $C D 4^{+} T$ tumbuh secara signifikan yang dapat meningkatkan kualitas hidup pasien, populasi sel $C D 4^{+} T$ yang terinfeksi dapat turun hingga 18,445 yang berarti efisiensi terapi obat dalam memblokir infeksi baru adalah 99\%, jumlah virus bebas dapat turun hingga 8,1 yang berarti efisiensi terapi obat dalam menghambat produksi virus bebas $100 \%$, serta respon imun yaitu sel sitotoksik dan antibodi juga ikut turun mendekati nol mengikuti sel yang terinfeksi dan virus dalam tubuh. Hasil simulasi sistem awal setelah pemberian kontrol dari model penyebaran virus HIV menunjukkan bahwa, populasi $C D 4^{+} T$ tumbuh secara signifikan yang dapat meningkatkan kualitas hidup pasien, populasi sel $C D 4^{+} T$ yang terinfeksi dapat turun hingga 18,445 yang berarti efisiensi terapi obat dalam memblokir infeksi baru adalah $99 \%$, jumlah virus bebas dapat turun hingga 8,1 yang berarti efisiensi terapi obat dalam menghambat produksi virus bebas $100 \%$, serta respon imun yaitu sel sitotoksik dan antibodi juga ikut turun mendekati nol mengikuti sel yang terinfeksi dan virus dalam tubuh.

\section{DAFTAR PUSTAKA}

[1] B. Dubey, P., Dubey, U.S., dan Dubey, "Modeling the role of acquired immune response and antiretroviral therapy in the dynamics of HIV," 2017.

[2] WHO, "Global health observatory (GHO) data, in: HIV/AIDS," WHO Press, 2014.

[3] Y. Spiritia, "Terapi Antiretroviral: Web Yayasan Spiritia," 2014 [Online]. Available: http://spiritia.or.id/li/bacali.php?lino=403.

[4] D. Wang, Y., "Viral dynamics model with CTL immune response incorporating antiretroviral therapy," J. Math.Biol, vol. 67, no. 4, pp. 901-934, 2013.

[5] D. . Nastitie dan Arief, "Analysis and Optimal Control in the Cancer Treatment Model by Combining Radio and Antiangiogenic Therapy," Int. J. Comput. Sci. Appl. Math., vol. 3, no. 2, 2017.

[6] A. Hamid, Ensiklopedia Biokimia dan Biologi Molekul. 2004

[7] Sudarman, "Jenis sel T dan fungsinya: Artikel Top," 2017.

[8] AhaBlogweb, "Antibodi: Pengertian, Fungsi, Struktur, Jenis: AhaBlogweb," 2016. [Online]. Available: http://www.ilmudasar.com/2016/10/pengertian-fungsi-dan-jenisjenis.html. .

[9] L. Perko, Differential Equations and Dynamical Systems. USA, 2001.

[10] Subiono, "Sistem Linier dan Kendali Optimal. Versi 2.2.1," ITS 2013.

[11] D. S. Naidu, Optimal Control Systems. USA: CRC Press LLC, 2002. 